V. Yu. Sliesarchuk ORCID https://orcid.org/0000-0001-8777-1243

O. A. Podpletnia ORCID https://orcid.org/0000-0003-4113-4665

N. V. Lohvynenko ORCID https://orcid.org/0000-0002-3694-7234

\title{
THE RESULTS OF IMPLEMENTATION OF THE UNIFIED STATE QUALIFICATION EXAMINATION OF PHARMACY STUDENTS AT DNIPROPETROVSK MEDICAL ACADEMY
}

\author{
Т. М. Потапова, В. Ю. Слєсарчук, О. А. Подплетня, Н. В. Логвиненко \\ ДЗ «Дніпропетровська медична академія МОЗ України», Дніпро \\ РЕЗУЛЬТАТИ ВПРОВАДЖЕННЯ ЄДИНОГО ДЕРЖАВНОГО \\ КВАЛІФІКАЦІЙНОГО ІСПИТУ У СТУДЕНТІВ-ПРОВІЗОРІВ \\ ДНІПРОПЕТРОВСЬКОЇ МЕДИЧНОЇ АКАДЕМІЇ
}

\begin{abstract}
The article analyzes the results of the Unified State Qualification Examination (USQE) implementation in order to assess the pharmacy students' education level during the Krok-1 licensed integrated examination and to compare these results with the national indicators. Considering that for the first time in 2019 a new qualitative assessment method of students' knowledge has been introduced in Ukraine, both Ukrainian and foreign third year pharmacy students have had the USQ examination at Dnipropetrovsk Medical Academy (DMA), which included two components: Krok-1 licensed integrated examination and professional English. The analysis of the obtained results has revealed some shortcomings of the student training program and drawn an attention to the solution to these problematic issues.

This comprehensive assessment of the pharmacy students' profile knowledge allows us to identify the training programs' shortcomings and provides an opportunity to increase the effectiveness of study at the academy in order to integrate Ukrainian specialists in the world medicine.

Key words: Unified State Qualification Examination (USQE); pharmacist; specialist; higher educational institution; professional orientation; integrated exam.
\end{abstract}

Анотація. У статті проведено аналіз результатів впровадження єдиного державного кваліфікаційного іспиту (ЄДКІ) для оцінки рівня знань у студентів-провізорів під час складання ліцензійного інтегрованого іспиту Крок-1 та порівняння цих результатів з національними показниками.

Зважаючи на те, що у 2019 р. в Україні вперше було впроваджено якісно новий інструмент оцінювання знань студентів, в Дніпропетровській медичній академії студенти-провізори 3 курсу, як громадяни України, так і іноземці, складали ЄДКІ, який мав такі дві складові, як: ліцензійний інтегрований комплексний іспит Крок-1 та англійська мова професійного спрямування. Аналіз отриманих результатів дозволив виявити деякі недоліки при підготовці студентів в академії та привернути увагу до рішення цих проблемних питань.

Таке комплексне оцінювання профільних знань студентів-провізорів дозволяє виявити слабкі сторони процесу навчання і надає можливість підвищити ефективність навчання в академії для інтегрування вітчизняних фахівців у світову медицину.

Ключові слова: єдиний державний кваліфікаційний іспит; провізор; фахівець; вища школа; професійна спрямованість; інтегрований іспит.

Introduction. The pharmaceutical market today needs skilful professionals who must have special medical, pharmaceutical and commercial knowledge. Only having such complex of high-level knowledge and skills can provide the young specialists with workplaces at modern pharmaceutical enterprises that meet all the international quality standards.

It is well known that patients increasingly seek for help from a pharmacist for various reasons without consulting a family doctor. That is why a health and even a life of

(C) T. M. Potapova, V. Yu. Sliesarchuk, O. A. Podpletnia, N. V. Lohvynenko 
a patient depend on the specialist's qualification. This situation requires a medical professional competence concerning symptoms and syndromes diagnosing and treatment. In this regard, the role of any contemporary pharmacist is not only to sell medicines but also to diagnose "disturbing" symptoms requiring urgent doctor's consulting. All the pharmacists should have not only pharmacy knowledge but also basic medical skills.

At the same time, having insufficient preventive and educational work in our country a pharmacist must have the skills and ability to inform the population (pharmacy customers) about a healthy lifestyle, to offer and explain indications for the use of the latest personal hygiene products which require the sociallyoriented specialist competencies formation.

The commercial skills are also important for all the pharmacists which include the ability to provide information on analogues of medicines which patients cannot buy due to the high price and availability of medicines at other pharmacies of the city as well as to be able to book the orders.

As a result, the professional training is an important issue in the modern pharmaceutical industry and scientific community influencing the national health protection and strengthening. All this requires certain standards for the higher educational institutions that educate future specialists.

The quality training requires not only systematic study but also the quality control improvement in accordance with European education standards.

The most countries have established a strong internal system of knowledge assessment at all the stages of study in the higher educational institutions preventing unqualified students from diplomas obtaining. Many countries have implemented a unified national exams system, providing a high level of training for medical and pharmacy professionals. In the USA a threestep exam system named the USMLE (United States Medical Licensing Examination) is required to obtain a medical degree and a practice medicine license. The similar forms of control are used in France, Germany and the United Kingdom [5]. The licensing exams also exist in such pharmaceutical education systems as the Pharmacist Evaluating Examination in Canada and the North American Pharmacist Licensure Examination (NAPLEX) in the United States [1].

Summing up, a qualitatively new assessment method has been introduced in Ukraine which allows us to integrate Ukrainian specialists into the world medicine.

The Unified State Qualification Exam (USQE) is a new comprehensive certification of medical students' and pharmacists' profile knowledge. For the first time in 2019 Ukrainian and foreign students have had this exam [2]. This exam is organized and administered by the Testing Center of the Ministry of Health Protection of Ukraine. It is also practiced in many developed countries around the world to test the knowledge of students which study in medical and pharmaceutical higher educational institutions.

The main purposes of this exam are the following [3]:

- assessment of the ability to use the knowledge and the key concepts of basic biomedical sciences understanding;

- integration of Ukrainian medicine into the world medicine;

- assessment of the level of comprehension of the subject foreign language, including basic medical sciences' terminology;

- promotion of motivated specialists' graduation which have the same employment opportunities as the other specialists abroad;

The compulsory components of the first USQE stage are the following:

- the Krok-1 integrated exam;

- professional foreign language exam;

- the basics of medicine international exam (for the students of Medicine specialty).

In case of failing one or both exam components, he or she can repeat an examination one more time. In case of failing the exam for the second time, the student has to be excluded.

The aim - to analyze the results of the Unified State Qualification Examination (USQE) implementation in order to assess the pharmacy students' education level during the Krok-1 licensed integrated examination and to compare these results with the national indicators.

Theoretical framework. All the third year students of Dnipropetrovsk Medical Academy have had the USQE in 2019, which included two components: the Krok-1 licensed integrated examination and professional English. The Pharmacy Krok-1 includes 200 test questions from 8 educational subjects with an approximate value of $12-14 \%$.

The average number of students who did not pass the Krok-1 exam in Ukraine is $21.6 \%$ and the average number of students who have not passed the professional foreign language exam is $5.6 \%$ [4].

According to the Testing Centre of the Ministry of Health Protection of Ukraine the average scores of exams passing by Ukrainian students is $69.6 \%$ [4]. 
Table 1 shows us the national indicator data according to the subtests. The worst indicators which did not reach a sufficient level (60.5\%) are physical and colloid chemistry and organic chemistry. The results of pathological physiology examination showed not very high level. In contrast to the previously mentioned, pharmacology showed, the best results (77.9\%).

$33.3 \%$ of Ukrainian pharmacy students in Dnipropetrovsk Medical Academy did not pass the Krok-1 exam (exceeding the national indicator by 1.5 times) and $11.1 \%$ did not pass English. Only one student did not pass the Krok-1 exam and the professional foreign language exam (11.1\%) because of repeated examination [4].

National pharmacy students have shown a low level of chemistry knowledge (organic chemistry, physical and colloid chemistry) as well as biomedical sciences knowledge (pathological physiology), which indicators did not reach the minimum acceptable level (60.5\%) (Table 2). At the same time, the indicators of pharmacology, microbiology and biological chemistry are quite high $-80.4 \%$, $81.5 \%$, $80.2 \%$.

The average number of foreign students whose language of study is Russian/Ukrainian and who did not pass the Krok-1 exam is $43.7 \%$.

Among the DMA pharmacy foreign students $25.0 \%$ did not pass the Krok-1 exam and all the anthers passed the professional foreign language exam.
As we can see (Table 3), all the higher educational institutions of Ukraine have the lowest exam scores in physical and colloidal chemistry, organic chemistry and pathological physiology.

Chemical and medical-biological subjects had been taught to the foreign students in the second academic year during one semester and the Krok-1 exam was carried out after the third academic year. The time gap between the lectures and examinations has influenced the low results $(25.0 \%)$. We also assume the possibility of contradiction between the level of foreign applicants' basic knowledge for their information perception ability and the requirements of higher educational institutions as well as a big language barrier (spoken and written skills) which inhibits understanding the fundamental subjects at a sufficient level.

In order to solve above mentioned problems all the academy's lectors provide obligatory classes related to the educational subjects included in the USQE. The academic department of independent testing and education quality monitoring carries out rectorial controls in order to identify training gaps of some students in some subjects. This provides the lectors with the opportunity to focus as much as possible on topics which have been not learned enough and to give the students more time to study at practical, seminar and laboratory classes.

Table 1. The national indicator of the Krok-1 test exam passing by Ukrainian students according to the subtests

\begin{tabular}{|l|c|c|c|c|c|c|c|c|c|}
\hline & $\begin{array}{c}\text { Average } \\
\text { indicator } \\
\text { among HEI } \\
*(\%)\end{array}$ & $\begin{array}{c}\text { Ana- } \\
\text { lytical } \\
\text { che- } \\
\text { mistry }\end{array}$ & $\begin{array}{c}\text { Organic } \\
\text { che- } \\
\text { mistry }\end{array}$ & $\begin{array}{c}\text { Physi- } \\
\text { cal and } \\
\text { colloid } \\
\text { chemistry }\end{array}$ & $\begin{array}{c}\text { Patho- } \\
\text { logic } \\
\text { physio- } \\
\text { logy }\end{array}$ & $\begin{array}{c}\text { Bioche- } \\
\text { mistry }\end{array}$ & $\begin{array}{c}\text { Pharma- } \\
\text { ceutical } \\
\text { botany }\end{array}$ & $\begin{array}{c}\text { Micro- } \\
\text { biology }\end{array}$ & $\begin{array}{c}\text { Pharma- } \\
\text { cology }\end{array}$ \\
\hline National indicator & 69.6 & 71.2 & 60.1 & 58.4 & 68.9 & 74.6 & 72.6 & 73.0 & 77.9 \\
\hline
\end{tabular}

Table 2. The indicator of the Krok-1 test exam passing by Ukrainian DMA students

\begin{tabular}{|c|c|c|c|c|c|c|c|c|c|}
\hline \multirow[b]{2}{*}{ Amount of students } & \multirow[b]{2}{*}{ Test (\%) } & \multicolumn{8}{|c|}{ Subtests (\%) } \\
\hline & & $\begin{array}{l}\text { Ana- } \\
\text { lytical } \\
\text { che- } \\
\text { mistry }\end{array}$ & $\begin{array}{l}\text { Organic } \\
\text { che- } \\
\text { mistry }\end{array}$ & $\begin{array}{l}\text { Physical } \\
\text { and col- } \\
\text { loidal che- } \\
\text { mistry }\end{array}$ & $\begin{array}{l}\text { Pathologi- } \\
\text { cal phy- } \\
\text { siology }\end{array}$ & $\begin{array}{l}\text { Biolo- } \\
\text { gical } \\
\text { che- } \\
\text { mistry }\end{array}$ & $\begin{array}{c}\text { Phar- } \\
\text { maceutical } \\
\text { botany }\end{array}$ & $\begin{array}{l}\text { Micro- } \\
\text { biology }\end{array}$ & $\begin{array}{l}\text { Pharma- } \\
\text { cology }\end{array}$ \\
\hline 9 & 69.9 & 76.7 & 52.4 & 52.3 & 59.3 & 80.2 & 75.7 & 81.5 & 80.4 \\
\hline
\end{tabular}

Table 3. The indicator of the Krok-1 test exam passing by foreign DMA students

\begin{tabular}{|c|c|c|c|c|c|c|c|c|c|}
\hline \multirow[b]{2}{*}{ Amount of students } & \multirow[b]{2}{*}{ Test (\%) } & \multicolumn{8}{|c|}{ Subtests (\%) } \\
\hline & & $\begin{array}{l}\text { Ana- } \\
\text { lytical } \\
\text { che- } \\
\text { mistry }\end{array}$ & $\begin{array}{c}\text { Organic } \\
\text { che- } \\
\text { mistry }\end{array}$ & $\begin{array}{l}\text { Physical } \\
\text { and col- } \\
\text { loidal che- } \\
\text { mistry }\end{array}$ & $\begin{array}{l}\text { Pathologi- } \\
\text { cal phy- } \\
\text { siology }\end{array}$ & $\begin{array}{c}\text { Biolo- } \\
\text { gical } \\
\text { che- } \\
\text { mistry }\end{array}$ & $\begin{array}{c}\text { Phar- } \\
\text { maceutical } \\
\text { botany }\end{array}$ & $\begin{array}{l}\text { Micro- } \\
\text { biolo- } \\
\text { gy }\end{array}$ & $\begin{array}{c}\text { Pharma- } \\
\text { cology }\end{array}$ \\
\hline 12 & 67.1 & 78.2 & 54.8 & 49.5 & 53.2 & 78.7 & 78.6 & 70.4 & 73 \\
\hline
\end{tabular}


The lectors work to create the most favorable conditions for the study of more than 24 subjects which included in the Krok-1 integrated exams (pharmacy) and the Krok- 2 integrated exams (pharmacy medicine technology, industrial medicine technology, clinical pharmacy). The students are actively involved in extra-curricular activities not only at home but also at practical classes where they learn to think creatively, to find different ways of solving difficult problems. The lectures are represented in the form of discussions. In such a way the students do not passively accept the ready-made content of the subject, as it before had been used in higher educational institutions, but also explore new themes of lectures improving their intellectual abilities and practical skills.

In addition, the department's lectors have created a remote electronic study course involving various subjects on the Moodle platform. This course consists of information material, tasks, situational tasks and tests based on the Krok-1, 2 basic concepts. Moreover, the Moodle platform allows us to place video files for the clearer and detailed research. The lectors carry out additional consultations after the main classes for the most useful preparation for the licensing exams, which are particularly useful in pharmacology.

Conclusions and Prospects for Research. In order to improve the results of the qualifying exams passing and to encourage students to comprehend the information properly as well as quality individual studying at home and at practical classes, the Department of General and Clinical Pharmacy's staff develops and implements the following strategy:

1. The Internet resource. A special department site is being developed by the Department of General and Clinical Pharmacy's staff which contains obligatory

\section{List of literature}

1. Білий А. К. Онлайн-підготовка студентів до ліцензійного іспиту «Крок 1. Фармація» з органічної хімії: поточний стан, перспективи впровадження / А. К. Білий, О. Ю. Воскобойнік, С. І. Коваленко // Медична освіта. - 2018. - № 4. - С. 26-30. - Режим доступу : http:// www.irbis-nbuv.gov.ua/cgi-bin/irbis_nbuv/ cgiirbis_64.exe_Mosv_2018_4_6/.

2. Сайт Міністерства охорони здоров'я [Електронний pecypc]. - https://moz.gov.ua/article/news/nova-jakist-medosviti-jak-i-koli-studenti-skladatimut-edki. and additional information for individual study and self-control.

2. The site contains all the bases of the Krok-1, 2 Pharmacy test integrated licensed exam depending on the subject and practical training.

3. The lectures are represented in the form of discussion, which requires students' self-preparation and presentation. The lectures are modernized and supported by video content (Smart TV).

4. A homework control is performed at all the practical classes (10-15 min.) The current control of a new topic is carried out by solving thematic problems which followed by a new topic test control at the end of the classes (15-20 min.)

5. The Moodle platform is being actively used to prepare for the Krok-1, 2 Pharmacy exam. Before each practical class all the lectors check the results of the students independent testing.

6. Educational work with the first-year students in order to encourage them to study professionally oriented subjects.

7. The DMA academic department has created additional optional English classes for Ukrainian and foreign students.

Prospects for further research:

1. The principles of educational subjects' interrelation and integration (basic knowledge in physiology, pathophysiology, biochemistry, organic and inorganic chemistry are necessary for pharmacology, pharmacy medicine technology and clinical pharmacy mastering).

2. Using a variety of understanding methods for the tests analyzing and memorizing (tests analysis using the cause-and-effect methods, all the lectures are accompanied by the tests).

3. Video collections creation for the lectures and practical classes.

3. Сайт Міністерства охорони здоров'я [Електронний ресурс]. - https://moz.gov.ua/edki.

4. Сайт Тест-центру при Міністерстві охорони здоров’я [Електронний ресурс]. - https://www.testcentr.org.ua.

5. Xuecheng Li. Status analysis and consideration of medical education system in China and abroad / Li Xuecheng, Liu Shulei // Higher Education of Social Science. - 2012. - Vol. 3, No. 2. - P. 40-44. doi:10.3968/ j. hess.1927024020120302.2002. 


\section{References}

1. Bilyi,A.K., Voskoboinik, O.Yu., \& Kovalenko, S.I. (2018). Onlian pidhotovka studentiv do litsensiinoho ispytu "Krok 1. Farmatsiia” z orhanichnoi khimii: potochnyi stan, perspektyvy vprovadzennia [Student online training for the Krok-1 Pharmacy licensing exam in organic chemistry: the current state, prospects for the future]. Medychna osvita Medical Education, 4. 26-30 Retrieved from: http://www. irbis-nbuv.gov.ua/cgi-bin/irbis_nbuv/cgiirbis_64.exe_ Mosv_2018_4_6/ [in Ukrainian].

2. Sait Ministerstva okhorony zdorovia [Site of Ministry of Health of Ukraine]. Retrieved from: https://moz.gov. ua/article/news/nova-jakist-medosviti-jak-i-koli-studentiskladatimut-edki [in Ukrainian].

3. Sait Ministerstva okhorony zdorovia [Site of Ministry of Health of Ukraine]. Retrieved from: https://moz.gov.ua/ edki [in Ukrainian].

4. Sait Test-tsentru pry Ministerstvi okhorony zdorovia [Site Test Centre by Ministry of Health of Ukraine]. Retrieved from: https://www.testcentr.org.ua [in Ukrainian]. 5. Li Xuecheng, \& Liu Shulei (2012). Status analysis and consideration of medical education system in China and abroad. Higher Education of Social Science, 3/2, 40-44. doi:10.3968/j. hess.1927024020120302.2002.

E-mail address for correspondence: tanypotapova777@gmail.com 